\title{
Sublocations of cancers of the oral cavity, oropharynx, hypopharynx, larynx, primary lymph node and other epidemiological features in a French Tropical Island in the Indian Ocean 2009-2013
}

\section{Antoine Delagranda $^{1 *}$, Romain Ferreira ${ }^{2}$, Xavier Dufour ${ }^{3}$, Maria Poisson $^{4}$, Gaelle Leterme $^{1}$}

\begin{abstract}
${ }^{1}$ Department of Otorhinolaryngology and Cervico-Facial Surgery, ${ }^{2}$ Department of Maxillo-Facial and Cervico-Facial Surgery, CHU Félix Guyon, 2 Allée des Topazes, Saint Denis, La Réunion, France ${ }^{3}$ Department of Otorhinolaryngology and Cervico-Facial Surgery, CHU Jean Bernard, 2 rue de la Milétrie, Poitiers, France ${ }^{4}$ Department of Maxillo-Facial and Cervico-Facial Surgery, $\mathrm{CH}$ Valenciennes, avenue Desandrouin, Valenciennes, France
\end{abstract}

Received: 06 March 2018

Accepted: 05 April 2018

\section{*Correspondence:}

Dr. Antoine Delagranda,

E-mail: antoine.delagranda@chu-reunion.fr

Copyright: (C) the author(s), publisher and licensee Medip Academy. This is an open-access article distributed under the terms of the Creative Commons Attribution Non-Commercial License, which permits unrestricted non-commercial use, distribution, and reproduction in any medium, provided the original work is properly cited.

\begin{abstract}
Background: This study had two objectives: firstly, to describe and compare sublocations of all cancer of the oral cavity, oropharynx, hypopharynx, larynx and primary carcinoma cervical lymph node diagnosed in Reunion Island, a tropical French overseas territory in the southern hemisphere between 2009 to 2013; and secondly others epidemiological features.

Methods: A retrospective study included 621 patients diagnosed with cancer of the oral cavity, oropharynx, hypopharynx or larynx or primary cervical node between 2009 and 2013 in Reunion Island. 13 possible sublocations of cancer for mouth are described, 14 for larynx, 12 for oropharynx, 3 for hypopharynx, 8 for primary cervical lymph node. Demographic characteristics, data on alcohol consumption, smoking habits, HPV infection, denutrition were analyzed.

Results: Cancer location consisted of oropharynx (36.2\%), larynx (25.6\%), oral cavity (20.8\%), hypopharynx $(13.8 \%)$, primary carcinoma lymph node $(3.6 \%)$. Sublocations in oral cavity mainly concerned palatin tonsil and base tongue. Vocal fold was the mostly frequent sublocation involved in larynx. Cancer in oral cavity were portion out more homogeneously. Excluding primary lymph node, sex ratio was 7.7 and mean age was 60 years. Cancer consisted of squamous cell carcinoma in $99.1 \%$ of patients. $340 / 375$ patients $(81.25 \%)$ showed alcohol abuse; $309 / 359(86.1 \%)$ were smokers; 31/184 (16.8\%) had HPV infection.

Conclusions: First study including all cases of pharyngolarynx and oral cavity cancer and depicting all sublocations involved in one series. We found no significant difference of distribution between sublocations for larynx but some for oropharynx and oral cavity compared to literature.
\end{abstract}

Keywords: Réunion Island, ENT cancer, Sublocations, larynx, Oral cavity, Pharynx

\section{INTRODUCTION}

In 2012, the IARC (International Agency for research on cancer) reported that incidence of cancer of oral cavity and lips (including tongue base and salivary glands) for male was $7.8 / 100,000$ in France. ${ }^{1}$ Incidence of larynx cancer was 5.62/100.000 for male in France. ${ }^{1}$ INCA (French national cancer Institute) gave incidence 37.8/100,000 for hypopharynx cancer. ${ }^{2}$ Data of incidence for oropharynx cancer alone are not available. We 
performed a retrospective study of epidemiological characteristics of patients with cancer of the oral cavity, pharynx (other than nasopharynx) or larynx diagnosed between 2009 and 2013 in Reunion Island. We compared data, particularly sublocations and prevalence of alcohol, nicotine dependence, HPV infection, according to gender.

\section{METHODS}

A retrospective study, approved by the French data protection commission (Commission Nationale d'Informatique et Liberté: CNIL), analyzed files for 621 patients with cancer of the oral cavity, pharynx, larynx, cervical primary nodes diagnosed between January 1, 2009 and December 31, 2013 in public $(n=3)$ or private $(n=3)$ health-care structures and followed up by an ENT or maxillofacial surgeon, radiotherapist or oncologist in Réunion Island. No other medical centers on the Island manage this kind of pathology, due to absence of relevant specialists. Inclusion was based on lists provided by the Island's 3 multidisciplinary ENT meetings, which were compared to data in the local registry. To optimize exhaustiveness, the Réunion ENT Society (Société des ORL de la Réunion: SORLOI), of which all ENT specialists in Réunion Island are members, was asked to provide data for patients who had left the Island for treatment following or without a local multidisciplinary team meeting. Exclusion criteria comprised: residence outside Réunion Island, precancerous pathology (dysplasia, in-situ carcinoma), recurrence and involvement by extension of a contiguous tumor, lymphopathy.

Epidemiological data comprised: histology, location and sublocation, TNM stage on the 2010 UICC classification, age, gender, smoking status (pack-years: data for 359 patients), alcohol status (threshold of 2 glasses of wine equivalent per day: data for 375 patients), HPV (Human Papilloma Virus) status (data for 184 patients) assessed by p16 protein expression on immunohistochemistry, with a threshold of $>10 \%$ on strong diffuse cytoplasmic and nuclear labeling. ${ }^{3}$ (HPV screening was not intended to establish a causal relation with cancer, for which p16 protein is insufficient). ${ }^{4}$

Malnutrition could be considered if BodyMassIndex-BMI $<18.5$ ( $<21$ for elderly patient more than 70 years old) or Loss weight $\geq 10 \%$ in 6 months, or serum-albumine $<30$ $\mathrm{g} / \mathrm{l}$ or NRI Nutritionnal risk index $<97.5$. $^{5}$

Panendoscopy results were used first for description of mucosal sublocations and compared to histological description after surgery if done. CT Scan, MRI, PET Scan if available were used to improve sublocations description. For primary lymph nodes, description involved histological results. Sublocations used are shown on Figures 1-4 and for primary lymph node we took AAO-HNS classification. ${ }^{6}$

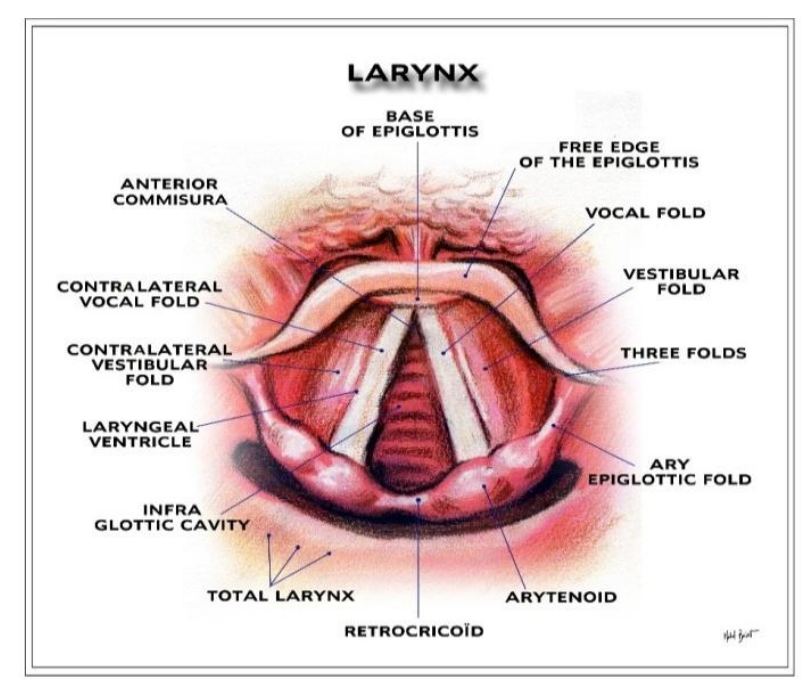

Figure 1: Larynx sublocations used (@A. Delagranda).

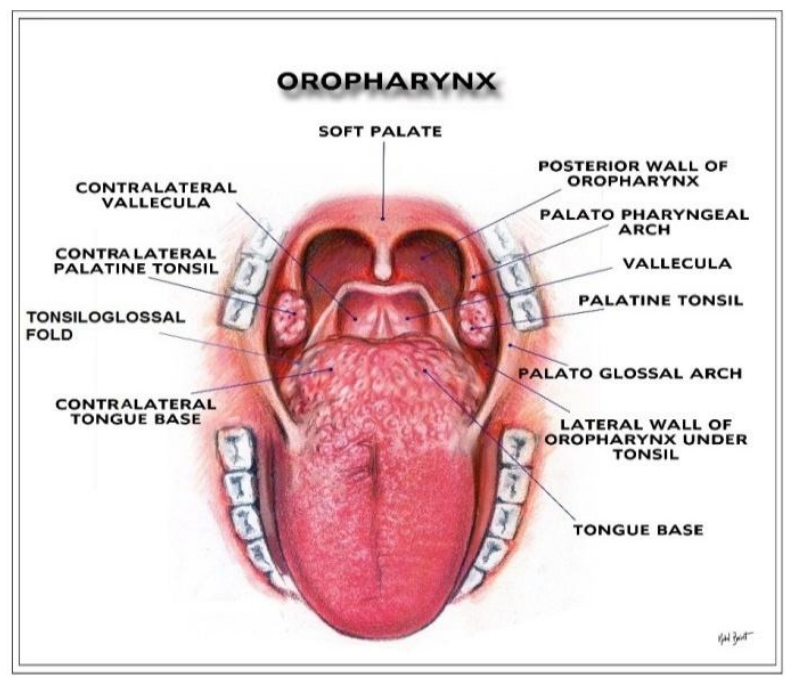

Figure 2: Oropharynx sublocations used (CA. Delagranda).

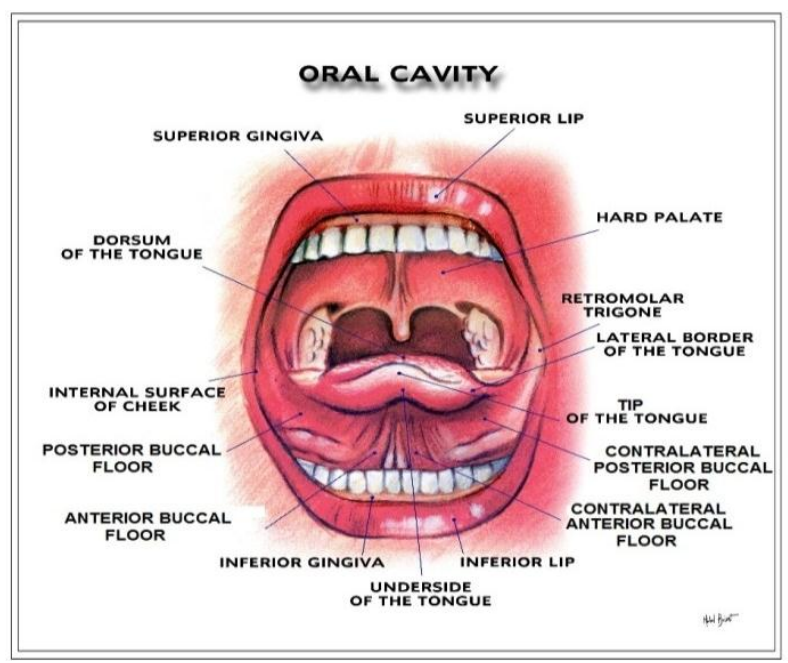

Figure 3: Oral cavity sublocations used (CA. Delagranda). 


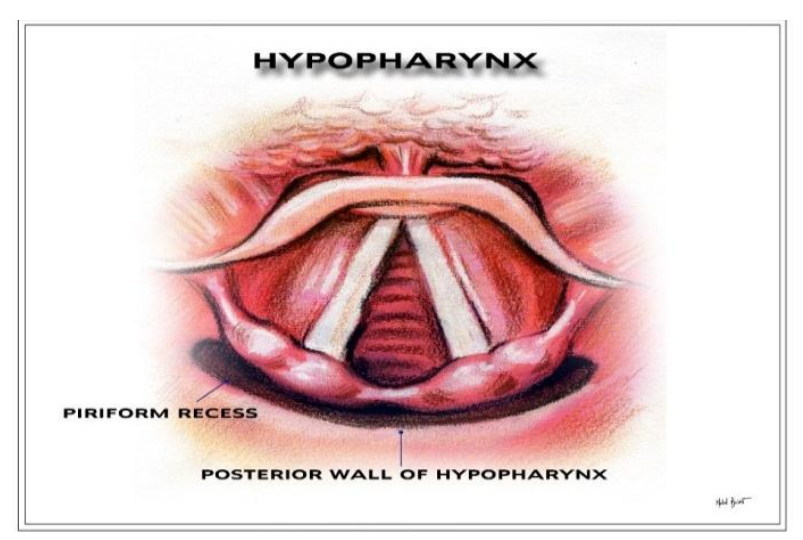

Figure 4: Hypopharynx sublocations used (CA. Delagranda).

Statistical analysis used SAS software, version 9.2 (SAS Institute, Cary, NC, USA), with $\mathrm{chi}^{2}$, Fisher exact, Student and Mann-Whitney U tests, with a significance threshold of $p<0.05$. The International Classification of Diseases (ICD-10) within the PMSI (Programme de Médicalisation des Systèmes d'Information) medical information system used in France was used to record cancer patients' data in the local registries. ${ }^{7}$

\section{RESULTS}

\section{Population and risk factors}

The sex ratio was 7.62: 549 male $(88.4 \%)$ and 72 female patients $(11.6 \%)$. Mean age was 60 years (range, 28-88 years) for males and 62 years (range, 38-90 years) for females. $18.6 \%$ of patients were born outside of Réunion Island.
$89.9 \%$ of patients, of whichever gender (357/397), were alcoholic, with significant male predominance: 315 male vs. 18 female; $p<0.0001$. 86.3\% (329/381) were smokers, with a mean consumption of 37 pack-years (range, 2-120 pack-years, for males and females), and once again significant male predominance: 321 male vs. 22 female; $\mathrm{p}<0.00001$. 16.8\% (31/184) had HPV infection; 22 of the 31 patients with HPV infection were nicotine-dependent.

Table 1 shows prevalence of alcohol and nicotine dependence and HPV infection according to gender and cancer location except for primary cervical lymph node: $\mathrm{HPV}+0 \%$ (0/7), alcohol 80\% (17/22), nicotine 92\% (20/22). There were significantly fewer smokers among patients with oral cavity cancer than for other locations: $\mathrm{p}=0.021 \mathrm{vs}$. oropharynx, $\mathrm{p}=0.031 \mathrm{vs}$ hypopharynx, and $\mathrm{p}<0.001$ vs. larynx. There were significantly fewer alcoholics among patients with oral cavity cancer than for the hypopharynx $(\mathrm{p}=0.009)$. HPV infection was detected in 31 of the 184 patients who were screened (16.2\%): 26 male, 5 female (NS). HPV rates were significantly higher $(p=0.0007)$ in cancer of the oropharynx $(32.4 \% ; 22 / 68)$ than for other locations: oral cavity $(12.2 \%$; 5/41), hypopharynx $(9.7 \% ; 3 / 31)$, or larynx $(2.3 \% ; 1 / 4)$. In oropharyngeal cancer, the palatine tonsils were significantly more often the sublocation infected by HPV (43.3\%; 22/68; $\mathrm{p}=0.01)$. $71 \%$ of HPV-positive patients (22/31) were also nicotine-dependent.

Concerning malnutrition $(\mathrm{n}=155), 13.27 \%$ patients had serum-albumine $<30 \mathrm{~g} / \mathrm{l}, 28.67 \%$ had BodyMassIndexBMI $<18,5$ or $<21$ if more than 70 years old and $29,67 \%$ Loss weight $\geq 10 \%$. Location of tumor did not affect Nutritional risk index $(\mathrm{p}=0.72)$.

Table 1: Study population characteristics.

\begin{tabular}{|c|c|c|c|c|c|c|c|}
\hline & & \multicolumn{2}{|l|}{ All } & \multicolumn{2}{|c|}{ Female } & \multicolumn{2}{|l|}{ Male } \\
\hline & & $\mathbf{n}$ & $\%$ & $\mathbf{n}$ & $\%$ & $\mathbf{n}$ & $\%$ \\
\hline \multirow[t]{4}{*}{ Oropharynx } & & 225 & 37.6 & 23 & 33.8 & 202 & 38 \\
\hline & Nicotine dependence & $121 / 135$ & 89.6 & $11 / 16$ & 68.7 & $110 / 119$ & 92.4 \\
\hline & Alcohol dependence & $113 / 135$ & 83.7 & $6 / 16$ & 37.5 & 107/119 & 89.9 \\
\hline & HPV infection & $22 / 68$ & 32.4 & $4 / 10$ & 40 & $18 / 58$ & 31 \\
\hline \multirow[t]{4}{*}{ Larynx } & & 159 & 26.5 & 10 & 14.7 & 149 & 28 \\
\hline & Nicotine dependence & $95 / 98$ & 96.9 & $4 / 5$ & 80 & $91 / 93$ & 97.8 \\
\hline & Alcohol dependence & $94 / 113$ & 83.1 & $2 / 6$ & 33.3 & 92/107 & 85.9 \\
\hline & HPV infection & $1 / 44$ & 2.3 & $0 / 0$ & 0 & $1 / 44$ & 2.3 \\
\hline \multirow[t]{4}{*}{ Oral cavity } & & 129 & 21.5 & 31 & 45.6 & 98 & 18.5 \\
\hline & Nicotine dependence & $53 / 69$ & 76.8 & $4 / 11$ & 36.4 & $49 / 58$ & 84.5 \\
\hline & Alcohol dependence & $48 / 67$ & 71.6 & $3 / 11$ & 27.3 & $45 / 56$ & 80.3 \\
\hline & HPV infection & $5 / 41$ & 12.2 & $0 / 6$ & 0 & $5 / 35$ & 14.3 \\
\hline \multirow[t]{4}{*}{ Hypopharynx } & & 86 & 14.4 & 4 & 5.9 & 82 & 15.5 \\
\hline & Nicotine dependence & $95 / 98$ & 96.9 & $1 / 2$ & 50 & $51 / 55$ & 92.8 \\
\hline & Alcohol dependence & $54 / 60$ & 90 & $1 / 2$ & 50 & $53 / 58$ & 91.4 \\
\hline & HPV infection & $3 / 31$ & 9.7 & $1 / 1$ & 100 & $2 / 30$ & 6.7 \\
\hline \multirow[t]{4}{*}{ Total } & & 599 & 100 & 68 & 11.4 & 531 & 88.6 \\
\hline & Nicotine dependence & $309 / 359$ & 86.1 & $20 / 34$ & 58.8 & $301 / 325$ & 92.6 \\
\hline & Alcohol dependence & $340 / 375$ & 81.25 & $12 / 35$ & 34.3 & 297 & 87.3 \\
\hline & HPV infection & $31 / 184$ & 16.9 & $5 / 17$ & 29.4 & $26 / 167$ & 15.6 \\
\hline
\end{tabular}


Table 2: TNM staging in study population.

\begin{tabular}{|c|c|c|c|c|c|c|c|c|c|c|c|c|}
\hline & \multicolumn{2}{|c|}{$\mathrm{T} 1$ and $\mathrm{T} 2$} & \multicolumn{3}{|c|}{ T3 } & \multicolumn{3}{|c|}{ T4 } & \multicolumn{3}{|c|}{ TOTAL } & \\
\hline & $\mathrm{n}$ & $\% \mathrm{~T}$ & $\% \mathrm{~N}+$ & $\mathrm{n}$ & $\% \mathrm{~T}$ & $\% \mathrm{~N}+$ & $\mathrm{n}$ & $\% \mathrm{~T}$ & $\% \mathrm{~N}+$ & $\mathrm{n}$ & $\% \mathrm{~T}$ & $\% \mathrm{~N}+$ \\
\hline Oropharynx & 112 & 49.8 & 68.6 & 49 & 21.8 & 75.5 & 64 & 28.4 & 78.6 & 225 & 37.6 & 69.8 \\
\hline Larynx & 75 & 47.2 & 26.6 & 28 & 17.6 & 50 & 56 & 35.2 & 57.1 & 159 & 26.5 & 41.3 \\
\hline Mouth & 68 & 52.7 & 27.9 & 21 & 16.3 & 47.6 & 40 & 31 & 54.8 & 129 & 21.5 & 40.4 \\
\hline Hypopharynx & 18 & 20.9 & 88.9 & 33 & 38.4 & 70.6 & 35 & 40.7 & 80.6 & 86 & 14.4 & 77.9 \\
\hline Total & 273 & 45.6 & 47.5 & 131 & 21.9 & 64.1 & 195 & 32.5 & 68.5 & 599 & 100 & 58.1 \\
\hline
\end{tabular}

Table 3: Primary lymph node sublocations.

\begin{tabular}{|lll|}
\hline Sublocation of primary node & n & \% \\
\hline Group IA & 0 & 0 \\
\hline Group IB & 1 & 2.08 \\
\hline Group IIA & 17 & 35.42 \\
\hline Group IIB & 5 & 10.42 \\
\hline Group III & 13 & 27.08 \\
\hline Group IV & 8 & 16.67 \\
\hline Group V & 4 & 8.33 \\
\hline Group VI & 0 & 0 \\
\hline Total & 48 & 100 \\
\hline
\end{tabular}

\section{Topography, type of cancer}

$99.2 \%(616 / 621)$ of cancers consisted of squamous cell carcinoma. The other 5 comprised: 2 cystic adenoid carcinomas, 1 adenocarcinoma, 1 accessory salivary gland cystadenocarcinoma, and 1 undifferentiated nasopharyngeal carcinoma exclusively involving the tonsils. There were 10 primary tumors synchronous to the ENT cancer (1.67\% of cases): 6 involving the esophagus, 2 the lungs and 2 the liver. Table 2 shows TNM stages, with significantly more $\mathrm{T} 3$ and $\mathrm{T} 4$ tumors in the hypopharynx than elsewhere $(\mathrm{p}<0.001)$. Metastasis sites ( $n=43$, due to multiple metastases) comprised the lungs in $59.5 \%$ of cases, liver in $19 \%$, bone in $16.7 \%$, mediastinum in $2.4 \%$, and brain in $2.4 \% ; 29.7 \%$ of patients had multiple metastasis sites.

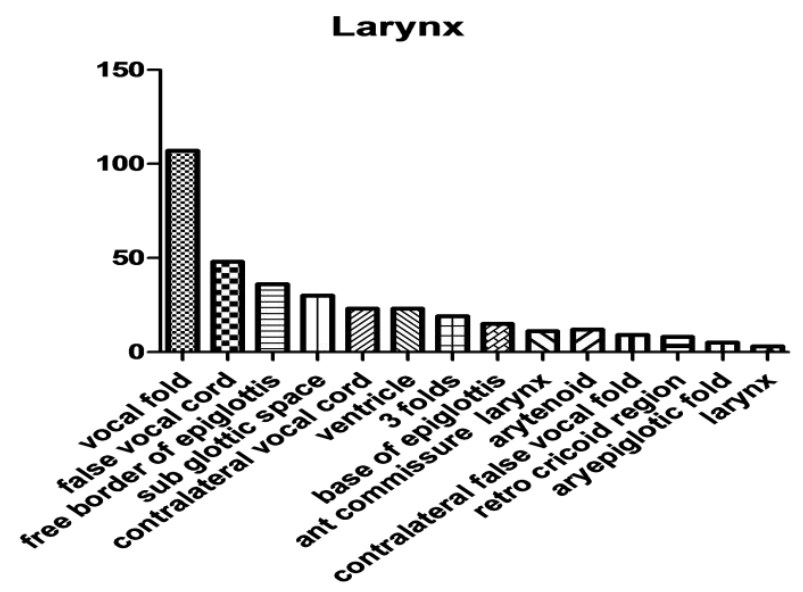

Figure 5: Sublocations larynx results.

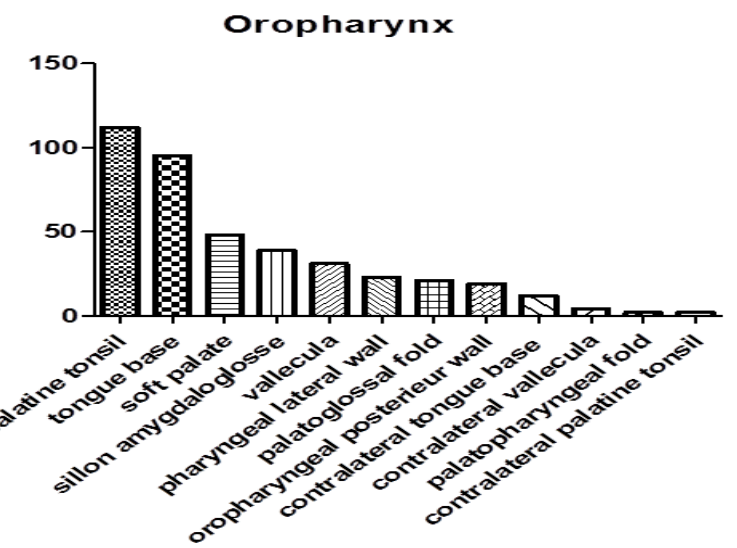

Figure 6: Oropharynx sublocations results.

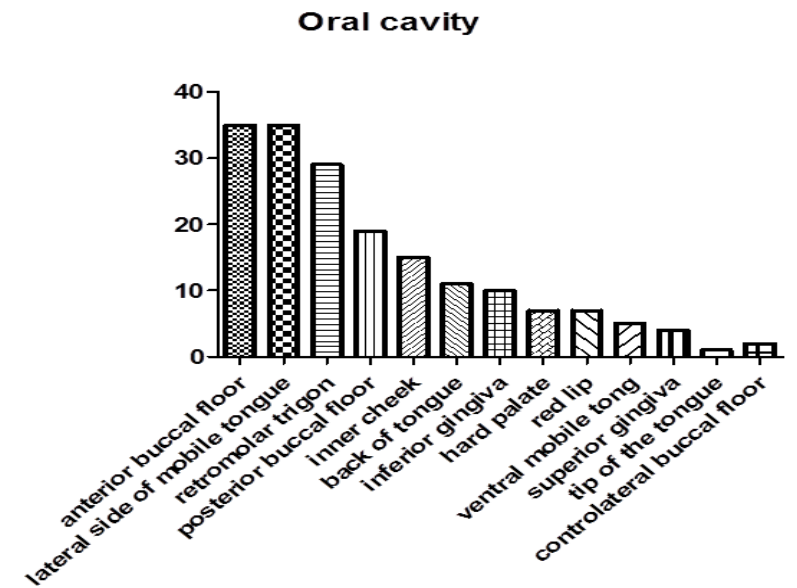

Figure 7: Sublocations oral cavity results. 


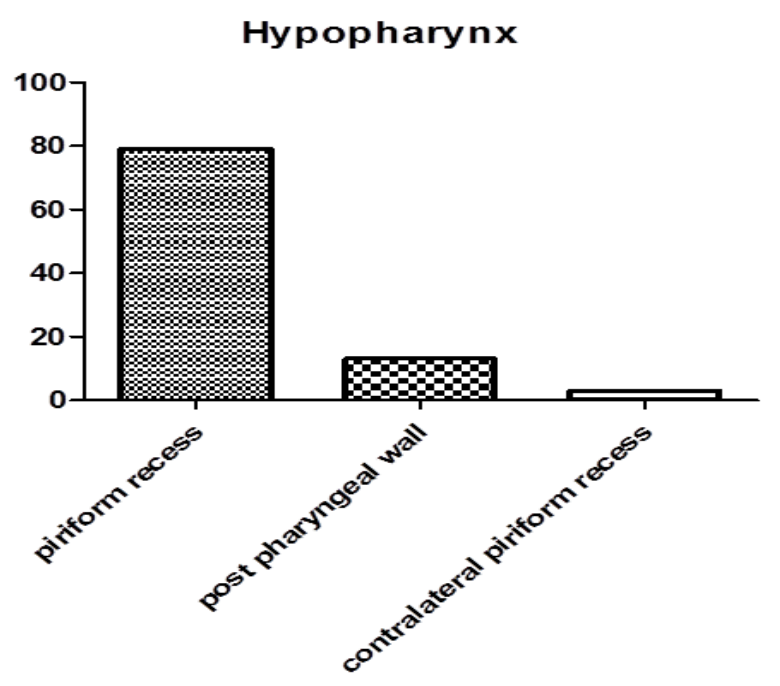

Figure 8: Hypopharynx sublocations results.

\section{Sublocations}

Sublocations described are shown on Figure 5 (larynx), Figure 6 (oropharynx), Figure 7 (oral cavity), Figure 8 (hypopharynx), Table 3 (cervical primary lymph node).

\section{DISCUSSION}

Squamous cell carcinoma was predominant in Réunion Island $(99.2 \%)$ in the present as in other series $(94.8 \%){ }^{8}$ Age and gender distributions are not specific in Réunion. ${ }^{8,9}$ Statistically, there were slightly more patients born outside of Réunion in the present series than in the general population of the Island: $18.56 \%$ versus $15.4 \%$, respectively $(\mathrm{p}=0.015) .7 \%$ of the present patients had history of ENT cancer, with a mean cancer-free interval of 7 years. Locations differed in $4 \%$ (e.g., larynx followed by oropharynx) and were identical in $3 \%$ of cases. The rate of synchronous cancer of the oral cavity, pharynx (excluding the nasopharynx) or larynx was low in Réunion: $0.7 \%$ versus $1.33 \%$ of 4,184 patients for Krishnatreva et al in India and $8.9 \%$ of 2,550 patients (exclusively laryngeal and hypopharyngeal cancer) for Spector et al. in the USA. ${ }^{10,11}$ Locations and rates $(6.51 \%)$ of metastasis at diagnosis were comparable to those of the literature (4-25\%). ${ }^{9-12}$ Réunion Island has an up-todate and accessible network of CT, MRI and PET scanners, enabling exhaustive extension assessment. Thus, although specialist medical density is slightly lower than in Metropolitan France, the low rate of synchronous cancer is probably not due to an assessment bias.

Sublocations are seldom reported in the literature except for the larynx, in which the glottis predominated in Poland: $47 \%$ of 12,888 patients for Bien et al and $39 \%$ of 100 patients for Wolny et al; likewise in the present 159 patients in Réunion, the vocal folds predominated, followed by the ventricular band. ${ }^{13,14}$ In the oropharynx, Melkane et al, reporting on 133 patients in the Paris region of France, found $66 \%$ tonsillar and $15.3 \%$ tongue- base involvement, whereas the present distribution was more even, with only $27.6 \%$ tonsillar involvement, $22.83 \%$ tongue base, $11.68 \%$ soft palate and $9.11 \%$ glossotonsillar sulcus, in 225 patients. ${ }^{15}$ In the oral cavity $(n=129)$, the distribution was similar to that reported by Mashberg et al in Italy $(n=102)$ except for the mobile tongue, which showed greater involvement in the present series (40.54\% versus $29.19 \%$ ) and the retromolar trigon which was less involved (4.05\% versus $16.22 \%){ }^{16}$

Cigarette consumption was 39 pack-years for males in Réunion Island, and 43 for Maier et al in Germany, in a series of 200 male patients. ${ }^{17}$ Smoking concerns at least $71.6 \%$ of males with oral cavity cancer and up to $90 \%$ of those with cancer of the hypopharynx. Réunion is the administrative Region in France with the third-highest rate of hospital admission for acute intoxication and alcohol-dependence syndrome, far in front of the other Overseas Départements and Regions: 7.69 admissions per thousand in Réunion in 2009, compared to a national rate of 4.36, and 2.8 and 4.33 for Martinique and Guadeloupe, respectively. ${ }^{18}$ Réunion Island is the first rum producer for France and the European economic community. ${ }^{19}$ The rate of oral cavity cancer in males was low and below the national average for oropharyngeal and hypopharyngeal cancer (Table 3), whereas Schlecht et al, reporting 784 cases in Brazil, found a higher rate of oral cancer associated with consumption of cachaça, a spirit similar to the rum traditionally drunk in Réunion. Interestingly, only $36.4 \%$ of females with oral cavity cancer were smokers, $27 \%$ drinkers and none HPVpositive; moreover, the oral cavity cancer was more frequent than oropharyngeal cancer, in contrast to the figures for males. ${ }^{20}$ Only 2 female patients had clinical history involving the oral cavity before their cancer diagnosis: 1 oral papillomatosis of 5 years' progression, and 1 dyskeratosis on biopsy 1 year before diagnosis. There were fewer HPV-positive cases than in the metaanalysis by Kreimer et al, with 5,046 patients from 25 countries and 60 studies. $^{21}$ Only the oropharynx was virtually as frequent, at $32.4 \%$ of cases compared to 32.6 $38.7 \%$ (95\% CI) for Kreimer et al, whereas other locations showed much lower rates: $12.2 \%$ versus 21.9 $25.1 \%$ for the oral cavity and $2.3 \%$ versus $21.8-26.3 \%$ for the larynx. ${ }^{21}$ The recent French multicenter Papillophar study on oropharyngeal cancer reported that $26.7 \%$ of cases implicated HPV (HPV DNA and E6/E7 mRNA). Comparison with Réunion Island cannot be precise, as the only criterion for HPV in the present study was p16 protein. In Réunion, the principal risk factor is still alcohol/nicotine synergy, without the trend for an increased rate of cancer implicating HPV found notably in North America. ${ }^{21}$ The present data-set includes all diagnoses made within the study period, but with some missing data due to differences in practices and how centers keep their records and to progression in practices over time; notably, HPV screening results were available (without serotype) in only 184 cases, although data for alcohol and nicotine were also not quite systematic. Malnutrition was quite the same in Reunion and 17 others 
French centers described by Pressoir about IMC (22.7 \pm 4.5 for Pressoir $(n=179)$ and $21.8 \pm 4.6$ for Réunion $(\mathrm{n}=155)){ }^{22}$ But if we consider loss weight, results vary: $5 \%$ for Langius in Holland $(n=1340), 17.6 \%$ for Pressoir in France, $19 \%$ for Jager-Wittenaar in Holland and $29.67 \%$ for us in Reunion. ${ }^{22-24}$ We must keep in mind that $26.8 \%$ of People are unemployed in Réunion versus $9.8 \%$ in France and there is $42 \%$ of people in high poverty versus $13,7 \%$ in France. ${ }^{25,26} 49 \%$ of the alcohol drunk in Réunion is spirits with high alcohol level while this is only $20 \%$ in France. ${ }^{19}$ The price of traditional rums is 50 to $60 \%$ less in Réunion than in France because of less taxes to help sugar cane producer an distilleries. ${ }^{19} 89,9 \%$ of our patients are alcoholic. These facts could contribute to the high percentage of malnutrition among our patient.

\section{CONCLUSION}

Usual risk factors (smoking, alcohol) are longer and greatly involved in oropharynx, mouth, larynx and hypopharynx cancer in Reunion because of habits and probably low price of spirits (one liter of traditional rum cost 6.15 euros/liter in 2016). Informations and help should be still given about tabacco and alcohol consumption and state should increase taxes for alcohol as wrote by Mété. ${ }^{19}$ HPV is not so much involved except in tonsil cancer. This has to be checked in future, to know if this trend differs from USA and some Western Europe's countries. Malnutrition described by significant loss weight is more important in Reunion than French other centers. We have to insist on pre, per and post therapeutic renutrition for the patients of the Island to avoid complications of treatment. ENT consultant, general practitioner and dentist should be aware, of mains sublocations involved in cancer, (e.g. vocal fold and false vocal fold in Larynx, e.g. palatine tonsil and tongue base in oropharynx, e.g. anterior floor of the mouth, lateral side of mobile tongue, retromolar trigon in oral cavity).

\section{ACNOWLEDGMENTS}

Our thanks to the ENT physicians, maxillofacial surgeons, pathologists, radiotherapists and oncologists of Réunion Island. And to Michel Brisset, our talented and well-loved draftsman, who sadly passed away in December of 2016.

Funding: No funding sources Conflict of interest: None declared Ethical approval: Not required

\section{REFERENCES}

1. Ferlay J, Soerjomataram I, Ervik M, Dikshit R, Eser S, Mathers C, et al. GLOBOCAN 2012 v1.0 cancer incidence and mortality worldwide IARC cancerbase $\mathrm{N}^{\circ} 11$. Lyon, France. Available from: http://globocan.iarc.fr. International Agency for Research on cancer, 2013. Accessed 20 December 2017.
2. (INCA) INclC Rapport sur la survie des personnes atteintes de cancer en France métropolitaine 19892013 -Partie 1 - Tumeurs solides, publié en février 2016.

3. UICC (2010) TNM Classification of Malignant Tumors - 8th Edition.

4. Guily JLS, Rousseau A, Baujat B, Périé S, Schultz $\mathrm{P}$, Barry B, et al. Oropharyngeal cancer prognosis by tumour HPV status in France: The multicentric Papillophar study. Oral Oncol. 2017;67: 29-36.

5. Chambrier C, Sztark F. French clinical guidelines on perioperative nutrition. Update of the 1994 consensus conference on "perioperative artificial nutrition after elective surgery in adults". Ann Fr Anesth Reanim 2011;30(4):381-9.

6. Lallemant B, Mallet Y, Ala-Eddine C, Lartigau E, Lefèbvre JL. Radiological and surgical classification of head and neck lymph node anatomy. Ann Otolaryngol Chir Cervicofac. 2003;120:216-24.

7. CIM Classification CIM10. http://wwwatihsantefr/sites/default/files/public/conte nt/2665/cim10_2015_final_0pdf. Accessed 20 December 2017.

8. Pruegsanusak K, Peeravut S, Leelamanit V, Sinkijcharoenchai W, Jongsatitpaiboon $\mathrm{J}$, et al. (2012) Survival and prognostic factors of different sites of head and neck cancer: an analysis from Thailand. Asian Pac J Cancer Prev. 13: 885-890.

9. Dietl B, Marienhagen J, Schaefer C, Pohl F, Kolbl O. Frequency and distribution pattern of distant metastases in patients with ENT tumors and their consequences for pretherapeutic staging]. Strahlenther Onkol. 2007;183:138-43.

10. Krishnatreya M, Rahman T, Kataki AC, Das A, Das AK, Lahkar K. Synchronous primary cancers of the head and neck region and upper aero digestive tract: defining high-risk patients. Indian $\mathbf{J}$ Cancer. 2015;50:322-6.

11. Spector JG, Sessions DG, Haughey BH, Chao KS, Simpson J, El Mofty S, et al. Delayed regional metastases, distant metastases, and second primary malignancies in squamous cell carcinomas of the larynx and hypopharynx. Laryngoscope. 2001;111:1079-87.

12. de Mones E, Bertolus C, Salaun PY, Dubrulle F, Ferrie JC, Temam $S$, et al. Initial staging of squamous cell carcinoma of the oral cavity, larynx and pharynx (excluding nasopharynx). Part 2: Remote extension assessment and exploration for secondary synchronous locations outside of the upper aerodigestive tract. SFORL guidelines. Eur Ann Otorhinolaryngol Head Neck Dis. 2012;130:107-12.

13. Bien S, Kaminski B, Zylka S, Mezyk R, Piasta Z (2008) Evolution of the epidemiology and clinical characteristics of larynx and hypopharynx carcinoma in Poland from 1991 to 2001. Eur Arch Otorhinolaryngol 2008;265 Suppl 1:S39-46.

14. Wolny E, Idasiak A, Wydmanski J, Miszczyk L. The difference of larynx cancer stage evaluation 
between clinical and pathological examinations. Otolaryngol Pol. 2006;60:15-20.

15. Melkane AE, Auperin A, Saulnier P, Lacroix L, Vielh $\mathrm{P}$, Casiraghi $\mathrm{O}$, et al. Human papillomavirus prevalence and prognostic implication in oropharyngeal squamous cell carcinomas. Head Neck. 2014;36:257-65.

16. Mashberg A, Merletti F, Boffetta P, Gandolfo S, Ozzello F, et al. Appearance, site of occurrence, and physical and clinical characteristics of oral carcinoma in Torino, Italy. Cancer. 1989;63:2522-7.

17. Maier H, Dietz A, Gewelke U, Seitz HK, Heller WD (1990) Tobacco- and alcohol-associated cancer risk of the upper respiratory and digestive tract. Laryngorhinootologie. 1990;69: 505-11.

18. Paille F, Moirand R. Realities of alcohol withdrawal. Rev Prat. 2015;65:845-6.

19. Mété D, Taxation of traditional rums in French overseas territory and public health: The example of Réunion Island NF, Revue d'épidémiologie et de santé publique. 2017;65:443-52.

20. Schlecht NF, Pintos J, Kowalski LP, Franco EL. Effect of type of alcoholic beverage on the risks of upper aerodigestive tract cancers in Brazil. Cancer Causes Control. 2001;12:579-87.

21. Kreimer AR, Clifford GM, Boyle P, Franceschi S Human papillomavirus types in head and neck squamous cell carcinomas worldwide: a systematic review. Cancer Epidemiol Biomarkers Prev. 2005; 14:467-75.
22. Pressoir M, Desné S, Berchery D, Rossignol G, Poiree B, Meslier M, et al. Prevalence, risk factors and clinical implications of malnutrition in French Comprehensive Cancer Centres. $\mathrm{Br} \mathrm{J}$ Cancer. 2010;102(6):966-71.

23. Langius JA, Zandbergen MC, Eerenstein SE, van Tulder MW, Leemans CR, Kramer MH, et al. Effect of nutritional interventions on nutritional status, quality of life and mortality in patients with head and neck cancer receiving (chemo) radiotherapy: a systematic review. Clin Nutr. 2013;32(5):671-8.

24. Jager-Wittenaar H, Dijkstra PU, Vissink A, van der Laan BF, van Oort RP. Roodenburg JL. Critical weight loss in head and neck cancer--prevalence and risk factors at diagnosis: an explorative study. Support Care Cancer. 2007;15(9):1045-50.

25. Insee-Economique, 2015. Available at: https://www.insee.fr/fr/statistiques/1285545. Accessed 20 December 2017.

26. IEDOM annual report (2015). La Réunion https://www.iedom.fr/IMG. Accessed 20 December 2017. Accessed on 3 August 2017.

Cite this article as: Delagranda A, Ferreira R, Dufour X, Poisson M, Leterme G. Sublocations of cancers of the oral cavity, oropharynx, hypopharynx, larynx, primary lymph node and other epidemiological features in a French Tropical Island in the Indian Ocean 2009-2013. Int J Otorhinolaryngol Head Neck Surg 2018;4:618-24. 